\title{
Recognise your privilege
}

Pablo Schyfter

The history of scientific and engineering disciplines is one characterised by various forms of social inequity, including genderbased discrimination (for example: Rossiter, 1982; Oldenziel, 1999). Women have been characterised as hampered by their sex and thus unable to practise science and engineering properly (or at best, not as effectively as men). Some key figures during the scientific revolution even suggested that scientific enterprises could prove dangerous and damaging to women's fragile minds and bodies. Physician Thomas Willis argued that "Women before men are troubled with the Affects called hysterical" due to "Weaker Constitutions of the Brain and Genus Nervosum" (quoted in Easlea, 1981, p. $69)$. A contemporary of Willis, philosopher Nicolas Malecbranche, confidently claimed that women's minds display “insufficient strength and reach to penetrate to the core of problems" (Easlea, 1981, p. 69).

Most explicit misogyny of this kind may have been routed since then, but problems persist. For instance, in a famous incident in 2005, the then-president of Harvard, Lawrence Summers, postulated that men's innately superior proficiency for science and engineering might explain differences in participation. Because the statement caused great debate, it's worth the reader's time to make up his or her mind about Summers' claims. His remarks can be found at: http://www.harvard. edu/president/speeches/summers_2005/ nber.php. A subsequent letter he wrote concerning the lecture can be found at: http://www.harvard.edu/president/ speeches/summers_2005/facletter.php.

Moreover, a recent study by the European Commission demonstrates that women remain minorities in science and engineering professions, enjoy disproportionately fewer higher-grade jobs and leadership positions, and face greater challenges securing research funding (ECDGRI, 2013).

The issue of sexism in science and engineering is one broadly acknowledged - for examples, see the recent reports: Botcherby \& Buckner (2012); Corbett \& Hill (2015); Hill et al. (2010) - even though only limited action has been taken to address it. Some examples are: the WISE Campaign (https://www.wisecampaign.org.uk/); the Ada Awards (http://adaawards.com/); the European Centre for Women and Technology (http://www.ecwt.eu/en/home); 1,000 Girls, 1,000 Futures (https://www.nyas.org/ programs/global-stem-alliance/100o-girls1000-futures/); and Gender InSITE (https:// genderinsite.net/). Lagesen (2007) offers an accessible and insightful sociological analysis of a campaign to increase women's participation in science and engineering.

Crucially, few people recognise that gender discrimination doesn't just harm women; it also gives many types of privilege to men. 
Male scientists and engineers tend to be more respected, paid higher salaries, promoted more easily, are more likely to be offered jobs, and more likely to have publications accepted and grants awarded (Hill et al., 2010). If we hope to combat gender discrimination, it isn't enough to lessen the harm done to women; we must also lessen the privilege given to men.

One way to do this involves encouraging men to recognise the benefits they have simply because they are men. That's why this recipe is for men. Recognise your privilege, and use that as a starting point to make a difference. This issue isn't about blame or guilt. Privilege isn't something that evil men conspire to achieve, nor is it something for which men should apologise. Privilege is something society as a whole produces, and it won't go away until people see that it exists and commit themselves to changing the situation. A necessary step is for men to realise that regardless of their personal attitudes, they have this benefit, and the benefit needs to go away.

\section{Ingredients}

- A field in science or engineering.

- An open mind.

- A commitment to equity.

- A desire to learn.

- Humility and tenacity.

\section{Method}

1. Learn about gender, science and engineering. Pick up a book, read a report, visit websites, get in touch with organisations. Here are two good places to start: read 'Why So Few?' and 'Solving the Equation' by the American Association of University Women (http://www.aauw.org/ research/why-so-few/); and visit the WISE Campaign website (https:// www.wisecampaign.org.uk/).

2. Make the lessons personal. Think back to your childhood, your school days, your years training in universities. Consider your work experience. Ask yourself questions like, "How many girls in my school took maths and science?" and "How many women are in my department?" Walk around your building and find portraits of celebrated scholars; how many are men? Wander around your campus and consider the names of buildings; how many of those names are masculine? Think back to the speakers you have seen at seminars, and the scholars who have been invited to the department; do men form a majority of them?

3. Talk to your women colleagues. Ask them if they have felt challenged by others' gender bias. Make sure that they know you are honestly interested. 


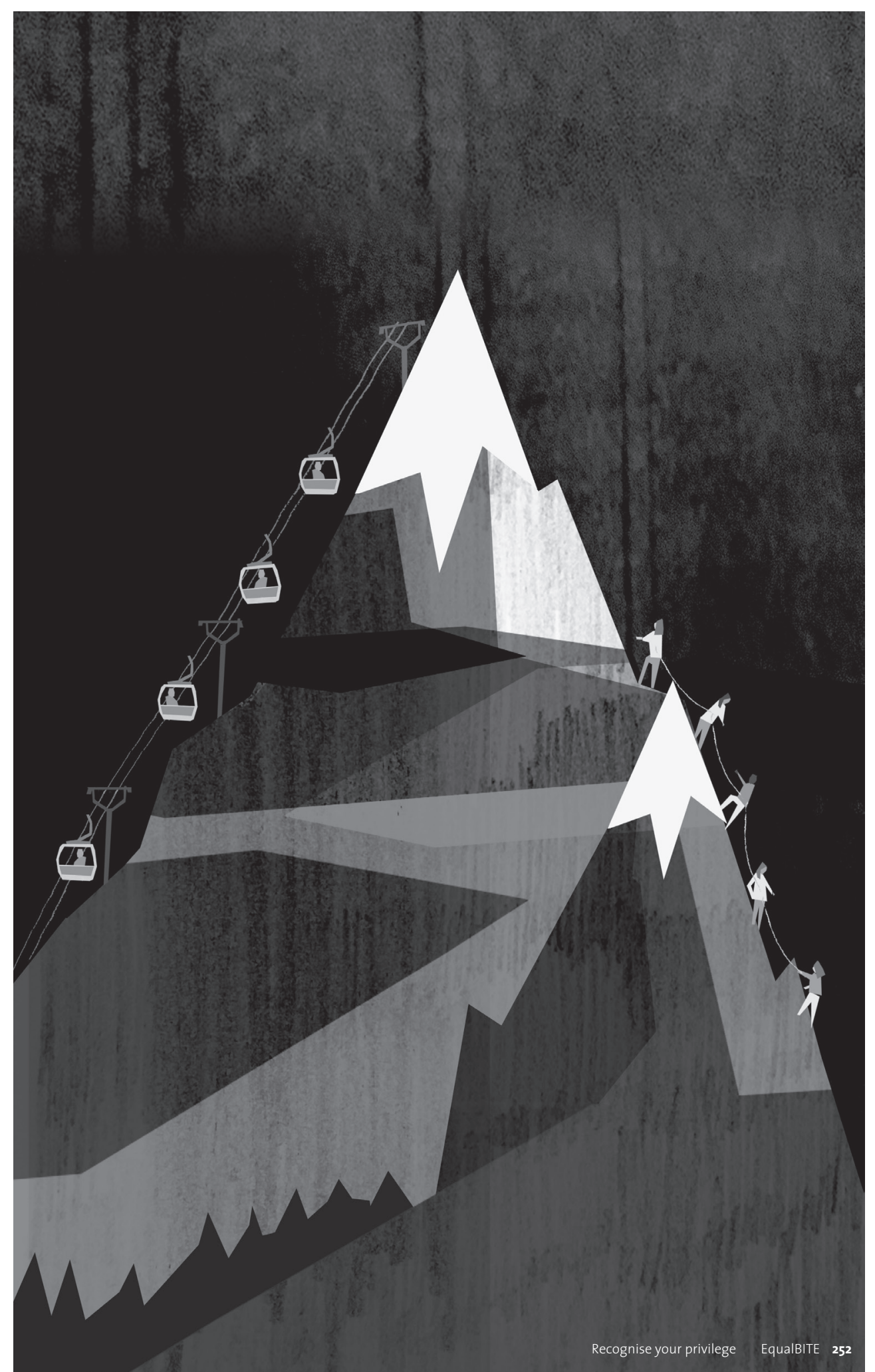

Pablo Schyfter - 9789463511438 
If you run into hesitation, mention things you have learned about gender, science and engineering from your readings.

4. Recognise your privilege out loud. Don't make this something that sits inside your head. Tell others what you have learned, and what it makes you feel.

5. Find partners and start changing things. Maybe your university has support groups for women in science and engineering. Perhaps there is an ongoing effort to better the situation. Engage with them.

6. Identify goals to pursue right away. For example, make sure that there is a better gender distribution of invited speakers. Ask colleagues from the social and political sciences to deliver talks on these issues. Bring up and discuss these problems at your next laboratory meeting. Encourage others to read the same texts you did.

\section{Cook's tips}

You'll almost certainly run into resistance, and it may even come from women colleagues. You may be accused of trying to blame people, or of calling someone a sexist. Don't just give up. Explain as best you can: this isn't about blame; this is about changing things for the better. The goal is not to find villains, but to open eyes.

We need to recognise privilege out loud. An open mind does little good without an active voice. 